\title{
Ghrelin protects the myocardium with hypoxia/reoxygenation treatment through upregulating the expression of growth hormone, growth hormone secretagogue receptor and insulin-like growth factor-1, and promoting the phosphorylation of protein kinase $B$
}

\author{
YANG LIU ${ }^{1,2}$, YANLING LIU ${ }^{2}$, GUOLIN LI ${ }^{2}$, ZHENGRONG CHEN ${ }^{3}$ and GUIXIONG GU ${ }^{1}$ \\ ${ }^{1}$ Department of Child Hygiene, Children's Hospital of Soochow University, Suzhou, Jiangsu 215000; \\ ${ }^{2}$ Department of Pediatrics, The Second Affiliated Hospital of Nanchang University, Nanchang, Jiangxi 330006; \\ ${ }^{3}$ Department of Respiratory Disease, Children's Hospital of Soochow University, Suzhou, Jiangsu 215000, P.R. China
}

Received April 3, 2018; Accepted August 7, 2018

DOI: $10.3892 / \mathrm{ijmm} .2018 .3886$

\begin{abstract}
Ghrelin is an endogenous ligand of growth hormone (GH) secretagogue receptor (GHSR) and has a number of biological effects, including heart protection. The present study aimed to reveal the positive effect of ghrelin on myocardium with hypoxia/reoxygenation $(\mathrm{H} / \mathrm{R})$ treatment and the involved molecular mechanisms. Successful construction of lentiviral expression vector (ghrelin-pLVX-Puro) was confirmed by colony polymerase chain reaction (PCR) verification. Primary rat cardiac myocytes were isolated and identified by immunofluorescence staining. Existence of red fluorescence of $\alpha$-sarcomeric actinin indicated the successful isolation. Following ghrelin transfection and H/R treatment, primary cells were divided into four groups: Control, H/R, empty (empty pLVX-Puro + H/R) and ghrelin (ghrelin-pLVX-Puro +H/R). Cell viability and apoptosis were evaluated by Cell Counting Kit- 8 (CCK-8) and Hoechst staining, respectively. The cell viability in the ghrelin group was significantly higher than that in the empty control group $(\mathrm{P}<0.05)$. The apoptosis rate in the ghrelin group was significantly lower than that in the empty control group $(\mathrm{P}<0.05)$. An ex vivo rat cardiac perfusion model was established. Following ghrelin incubation and $\mathrm{H} / \mathrm{R}$ treatment, ex vivo myocardium
\end{abstract}

Correspondence to: Professor Zhengrong Chen, Department of Respiratory Disease, Children's Hospital of Soochow University, Suzhou, Jiangsu 215000, P.R. China

E-mail: chen_zheng_rong@163.com

Professor Guixiong Gu, Department of Child Hygiene, Children's Hospital of Soochow University, 303 Jingde Road, Suzhou, Jiangsu 215000, P.R. China

E-mail: ggx_2001@sina.com

Key words: ghrelin, cardiac myocytes, myocardium, hypoxia/ reoxygenation, protein kinase $\mathrm{B}$ was divided into four groups: Control, sham, H/R and ghrelin (ghrelin $+\mathrm{H} / \mathrm{R}$ ). Immunohistochemical analysis demonstrated that ghrelin increased the integrity of cardiac myocytes, and decreased shrinkage and apoptosis. mRNA and protein expression levels of GH, GHSR, insulin-like growth factor-1 (IGF-1), protein kinase B (Akt), phosphorylated Akt (p-Akt) were determined by reverse transcription (RT)-PCR, western blot analysis and immunohistochemical analysis. Ghrelin upregulated the mRNA and protein expression levels of $\mathrm{GH}$, GHSR and IGF-1, and increased the ratio of p-Akt to Akt protein level (p-Akt/Akt) in cardiac myocytes and myocardial tissues with $\mathrm{H} / \mathrm{R}$ treatment. In conclusion, ghrelin protected the myocardium with $\mathrm{H} / \mathrm{R}$ treatment through upregulating the expression of GH, GHSR and IGF-1, and promoting the phosphorylation of Akt. This would provide promising insights into the treatment of hypoxic myocardial injury by ghrelin.

\section{Introduction}

In light of social continuous improvement, rapid economic development and aggravation of population aging, the number of patients with cardiovascular disease has increased annually and cardiovascular disease has become an important factor that threatens human health (1). The tolerance of myocardial cells to hypoxia injury is poor, and hypoxia-ischemia can lead to abnormal cardiac electric activity, necrosis of myocardial cells and cell apoptosis, which may induce various cardiovascular diseases (2-4). At present, there is no known radical cure. The normal physiological function of the heart can be maintained only by pharmacological remission and stent implantation. Therefore, it is urgent to develop novel treatment methods to improve and repair the damaged myocardial cells, eventually achieving a radical cure.

Ghrelin is a specific growth hormone $(\mathrm{GH})$ secretagogue (GHS) containing 28 amino acid residues, which was identified in 1999 (5). It is an endogenous ligand for the GHS receptor (GHSR). GHSR abundantly exists in the cardiovascular system. The expression of GHSR mRNA is also detected in human 
atrial and ventricular myocytes. Ghrelin combines with a $\mathrm{G}$ protein coupled receptor to regulate GH (6-8). Ghrelin and its receptors are widely distributed in all tissues and organs, and have numerous biological effects, including increasing appetite, promoting fat accumulation and protecting the heart $(8,9)$. In particular, as a vasoactive peptide, it has a number of protective and repair effects on the cardiovascular system $(8,9)$. A number of studies have indicated that in addition to GHSR, ghrelin may have other unknown receptors in the cardiovascular system and may work independently of GH (10-13). The present study investigated the effect of ghrelin on myocardial repair and function through investigating the expression of ghrelin in the myocardial cells to provide solid support for the treatment of hypoxic myocardial injury by ghrelin.

Ghrelin has been known to exert positive effects in cardiovascular protection and repair. Although based on a cardiopulmonary bypass (CPB) study, Cao et al (14) reported that cardioprotective effects elicited by ghrelin may contribute toward the inhibition of inflammatory response through the protein kinase B (Akt) activated pathway, this is only one of a number of theories regarding the mechanism of ghrelin and there remains a great possibility of other mechanisms of action. Insulin-like growth factor-1 (IGF-1) is a type of active polypeptide that is necessary for $\mathrm{GH}$ to produce a physiological effect. IGF-1 has functions of regulating physiological and pathological states of the heart, relaxing blood vessels, decreasing vascular resistance and increasing cardiac blood flow (12). Therefore, the expression of IGF-1 is an important indicator of the normal function of myocardial cells and tissues. Akt is a kind of Ser/Thr protein kinase and serves an important role in cell survival and apoptosis (15). Akt is a significant component of the phosphatidylinositol 3-kinase (PI3K)/Akt signaling pathway that is a classic signaling pathway serving an important role in numerous physiological and pathological processes, including cell survival, differentiation, growth and apoptosis via regulating gene expression (16). Akt is generally overexpressed in damaged or apoptotic cells, thereby promoting the PI3K/Akt signaling pathway to aggravate cell apoptosis. By contrast, Akt will be phosphorylated in normal cells to inhibit its activity, such that the level of phosphorylated Akt (p-Akt) will be upregulated and the cells or tissues are improved and repaired $(17,18)$.

Therefore, the present study further revealed the molecular mechanism of ghrelin expression improving and repairing cardiac myocytes and myocardium by investigating $\mathrm{GH}$, GHSR, IGF-1, Akt and p-Akt targets associated with cardiomyocyte metabolism and apoptosis. This would also provide promising insights into the treatment of hypoxic myocardial injury by ghrelin.

\section{Materials and methods}

Materials and animals. BSA blocking buffer (5\%), typsin-EDTA $(0.25 \%)$ and type II collagenase were obtained from Beijing Solarbio Science \& Technology Co., Ltd. (Beijing, China). 3,3'-Diaminobenzidine (DAB) developing kit (cat. no. CW0125), TRIzol reagent (cat. no. CW0580S), Ultrapure RNA extraction kit (cat. no. CW0581M), HiFiScript cDNA synthesis kit (cat. no. CW2569M), UltraSYBR mixture (cat. no. CW0957M) and 2X Taq MasterMix were obtained from CWbio Co., Ltd. (Beijing, China). DMEM/F12 (1:1) and Lipofectamine 3000 reagent were purchased from Thermo Fisher Scientific, Inc. (Waltham, MA, USA). Fetal bovine serum (FBS; cat. no. SKU 04-007-1A) was purchased from Biological Industries (Kibbutz Beit Haemek, Israel). Hoechst apoptosis kit was purchased from Beyotime Institute of Biotechnology (Haimen, China). Endo-free plasmid mini kit II (cat. no. D6950-01) was obtained from Omega Bio-Tek, Inc. (Norcross, GA, USA). TIANgel midi purification kit (cat. no. DP209) was purchased from Tiangen Biotech Co., Ltd. (Beijing, China). pLVX-Puro vector (VECT231322) was purchased from Huayueyang Bio (Beijing, China). pUC57 plasmid was purchased from BioVector NTCC, Inc. (Beijing, China). Ghrelin-pUC57 plasmid was routinely cloned in our laboratory. Mouse anti-GH antibody (cat. no. ab9821; dilution, 1:1,200), rabbit anti-IGF-1 antibody (cat. no. ab182408; dilution, 1:1,000), rabbit anti-Akt antibody (cat. no. ab81283; dilution, 1:1,000) and rabbit anti-p-Akt antibody (cat. no. ab38449; dilution, 1:1,000) were purchased from Abcam (Cambridge, MA, USA). Mouse anti- $\beta$-actin antibody (cat. no. TA-09; dilution, 1:2,000), horseradish peroxidase (HRP)-conjugated goat anti-mouse $\operatorname{IgG}(\mathrm{H}+\mathrm{L}$; cat. no. ZB-2305; dilution, $1: 2,000)$ and HRP-conjugated goat anti-rabbit $\operatorname{IgG}(\mathrm{H}+\mathrm{L}$; cat. no. ZB-2301; dilution, 1:2,000) were obtained from OriGene Technologies, Inc. (Beijing, China). Rabbit anti-GH antibody (cat. no. bs-0467R), rabbit anti-GHSR antibody (cat. no. bs-11529R; dilution, 1:1,200), rabbit anti-IGF-1 receptor antibody (cat. no. bs-0227R), rabbit anti-Akt antibody (cat. no. bs-0115R), rabbit anti- $\alpha$-sarcomeric actinin antibody (cat. no. bs-10367R) and ghrelin (cat. no. bs-0467P) were from BIOSS (Beijing, China). HRP-conjugated polymer anti-rabbit IgG (cat. no. SV0002) was obtained from Boster Biological Technology (Pleasanton, CA, USA).

A total of 28 specific pathogen-free (SPF) male Sprague Dawley (SD) rats (aged 8 weeks; weight, $300 \pm 30 \mathrm{~g}$ ) and 8 SPF neonatal SD rats (4 male and 4 female; aged 1-3 days) were obtained from Hunan Slac JD Laboratory Animal Co., Ltd. [License SCXK(XIANG)2016-0002; Hunan, China]. The rats were housed with ad libitum access to water and food in an environment of $20-26^{\circ} \mathrm{C}, 40-70 \%$ relative humidity and a $12 / 12 \mathrm{~h} \mathrm{light/dark}$ cycle. The study protocol was reviewed and approved by the Ethics Committee of Children's Hospital of Suzhou University (approval no. 2016LW009).

Construction of ghrelin expression vector. Ghrelin-pUC57 plasmid was digested by incubating with BamHI and EcoRI at $37^{\circ} \mathrm{C}$ for $2 \mathrm{~h}$. The enzyme digestion system $(50.0 \mu \mathrm{l})$ contained 10X Tango buffer $5.0 \mu \mathrm{l}$, ghrelin-pUC57 $(1 \mu \mathrm{g}) 4.0 \mu \mathrm{l}, \mathrm{BamHI}$ (10 U) $1.0 \mu 1, E c o R I(10 \mathrm{U}) 1.0 \mu \mathrm{l}$ and $\mathrm{ddH}_{2} \mathrm{O} 39.0 \mu \mathrm{l}$. Next, the product was separated by $1 \%$ agarose gel electrophoresis. The gel was visualized on an electrophoresis imaging system (Tanon1600; Tanon Science and Technology Co., Ltd., Shanghai, China). Target fragment (363 bp) was harvested quickly under the imaging system to prevent the destruction of the gene fragments by ultraviolet radiation. DNA was recovered from the harvested gel with a gel extraction kit according to the manufacturer's protocol.

pLVX-Puro vector was digested with BamHI and EcoRI at $37^{\circ} \mathrm{C}$ for $2 \mathrm{~h}$. The enzyme digestion system $(10.0 \mu \mathrm{l})$ was composed of 10X Tango buffer 1.0 $\mu 1$, pLVX-Puro vector 
$(0.5 \mu \mathrm{g}) 2.0 \mu \mathrm{l}, \mathrm{BamHI}(10 \mathrm{U}) 1.0 \mu \mathrm{l}, E c o \mathrm{RI}(10 \mathrm{U}) 1.0 \mu \mathrm{l}$ and $\mathrm{ddH}_{2} \mathrm{O} 5.0 \mu \mathrm{l}$. The product was also separated by $1 \%$ agarose gel electrophoresis. The gel was visualized on an electrophoresis imaging system (Tanon1600; Tanon Science and Technology Co., Ltd.). Target fragment ( 8,102 bp) was harvested and recovered using a gel purification kit according to the manufacturer's protocols.

The ghrelin gene was ligated to pLVX-Puro vector in a $20 \mu \mathrm{l}$ system (linear vector $4.0 \mu \mathrm{l}$, target gene $1.0 \mu \mathrm{l}$, 10X ligation buffer $2.0 \mu \mathrm{l}$, T4 DNA ligase (5 U/ $\mu \mathrm{l}) 0.3 \mu \mathrm{l}$ and $\mathrm{ddH}_{2} \mathrm{O}$ $12.7 \mu \mathrm{l})$ at $22^{\circ} \mathrm{C}$ for $3 \mathrm{~h}$. Next, the ligated product was transformed into DH5 $\alpha$. The transformation product was coated on an LB plate containing $100 \mu \mathrm{g} / \mathrm{ml}$ ampicillin and incubated at $37^{\circ} \mathrm{C}$ for $22 \mathrm{~h}$

Two single colonies were selected from the ghrelin-pLVXPuro plate following overnight incubation to perform colony polymerase chain reaction (PCR) verification. The PCR amplification system $(20.0 \mu \mathrm{l})$ was comprised of $2 \mathrm{X}$ Taq MasterMix $10.0 \mu \mathrm{l}$, template $1.0 \mu \mathrm{l}$, forward primer $(10 \mu \mathrm{m}) 1.0 \mu \mathrm{l}$, reverse primer $(10 \mu \mathrm{m}) 1.0 \mu \mathrm{l}$ and $\mathrm{dd}_{2} \mathrm{O} 7.0 \mu \mathrm{l}$. Sequences of the forward and reverse primers were: 5'-CACGCTGTTTTG ACCTCCAT-3' and 5'-GGATGTGGAATGTGTGCGAG-3'. PCR parameters were as follows: Pre-denaturation at $94^{\circ} \mathrm{C}$ for $2 \mathrm{~min}$, denaturation at $94^{\circ} \mathrm{C}$ for $30 \mathrm{sec}$, annealing at $55^{\circ} \mathrm{C}$ for $30 \mathrm{sec}$, elongation at $72^{\circ} \mathrm{C}$ for $45 \mathrm{sec}(30$ cycles of denaturation to elongation), sufficient elongation at $72^{\circ} \mathrm{C}$ for $10 \mathrm{~min}$. The PCR product was separated by $1 \%$ agarose gel electrophoresis. The gel was visualized on an electrophoresis imaging system (Tanon1600; Tanon Science and Technology Co., Ltd.).

The ghrelin-pLVX-Puro colonies were incubated in LB broth containing $100 \mu \mathrm{g} / \mathrm{ml}$ ampicillin overnight. The ghrelin-pLVX-Puro vectors were extracted using the plasmid extraction kit according to the manufacturer's protocols for the subsequent experiments.

Isolation and identification of primary neonatal rat cardiac myocytes. A total of 8 neonatal SD rats (aged 1-3 days) were anaesthetized by inhaling isoflurane (2\%) and were sacrificed by cervical dislocation. Following the heart being isolated, the apex cordis was obtained using scissors and immersed in precooled PBS. The apex cordis was washed three times with PBS to remove residual blood and uniformly cut into $\sim 1 \mathrm{~mm}^{3}$ fragments in $0.1 \%$ trypsin. The apex cordis fragments were trypsinized in $0.1 \%$ trypsin at $37^{\circ} \mathrm{C}$ for $6 \mathrm{~min}$. Following continuous agitating and natural sedimentation, the supernatant was removed. Next, the tissues were trypsinized in a mixture of $0.08 \%$ trypsin and $0.05 \%$ type II collagenase at $37^{\circ} \mathrm{C}$ for $5 \mathrm{~min}$. During this $5 \mathrm{~min}$, agitating was conducted for $3 \mathrm{~min}$. The supernatant was collected into another pre-cooled centrifuge tube and an equal volume of DMEM/F12 containing $10 \%$ FBS was added to terminate the trypsinization. The aforementioned trypsinization steps were repeated 3-4 times. All the trypsinized mixture was filtered into centrifuge tubes through a 200 -mesh sieve. The filtrate was centrifuged at $800 \mathrm{x} \mathrm{g}$ at $4^{\circ} \mathrm{C}$ for $8 \mathrm{~min}$ and the pellets were resuspended in $20 \%$ DMEM/F12. Following transfer to culture plates, cells were cultured at $37^{\circ} \mathrm{C}$ in $5 \% \mathrm{CO}_{2}$.

Cells were washed with PBS three times for 3 min each time and fixed in $4 \%$ paraformaldehyde at room temperature for 15 min. Following washing with PBS again, cells were incubated in $0.5 \%$ Triton $\mathrm{X}-100$ at room temperature for 20 min. Following washing with PBS, cells were incubated in $5 \%$ BSA buffer at $37^{\circ} \mathrm{C}$ for $30 \mathrm{~min}$. The BSA buffer was removed and diluted rabbit anti- $\alpha$-sarcomeric actinin antibody (1:300) was added at $4^{\circ} \mathrm{C}$ overnight. Cells were washed with PBS and incubated in secondary antibody buffer (1:200) at $37^{\circ} \mathrm{C}$ for $30 \mathrm{~min}$. Following washing, cells were stained in 4',6-diamidino-2-phenylindole (DAPI) solution for $5 \mathrm{~min}$ in the dark. The remaining DAPI was removed by PBS washing. Finally, the culture dish was mounted with $20 \%$ glycerin and visualized under a fluorescence microscope (magnification, $\mathrm{x} 200)$.

Cell transfection and hypoxia/reoxygenation $(H / R)$ treatment. Cells were divided into four groups: Control, H/R, empty (empty pLVX-Puro plasmid $+\mathrm{H} / \mathrm{R}$ ) and ghrelin (ghrelin-pLVX-Puro plasmid $+\mathrm{H} / \mathrm{R}$ ). The plasmid was mixed with Lipofectamine 3000 reagent according to the manufacturer's protocol. When cell confluence reached $80 \%$, cells were incubated with a mixture of plasmid and Lipofectamine 3000 at $37^{\circ} \mathrm{C}$ and $5 \% \mathrm{CO}_{2}$ for 4 days. Subsequently, hypoxia $(4 \mathrm{~h})$ and reoxygenation $(1 \mathrm{~h})$ treatments were performed. Cells in the control group did not undergo any treatments, including transfection or $\mathrm{H} / \mathrm{R}$. H/R treatment is a common method used to establish the model of myocardial injury (19).

Cell viability. At 24,48 and $72 \mathrm{~h}$ after the aforementioned treatments, Cell Counting Kit-8 (CCK-8) reagent (10 $\mu \mathrm{l})$ was added to each well and then cells were cultured at $37^{\circ} \mathrm{C}$ in $5 \% \mathrm{CO}_{2}$ for $4 \mathrm{~h}$. The absorbance was determined at $550 \mathrm{~nm}$ on a microplate reader. The cell viability was calculated accordingly.

Cell apoptosis. Cells were seeded into the 6-well plate where coverslips had been laid. Once the confluence reached $\sim 80 \%$, the treatments, including transfection and/or $\mathrm{H} / \mathrm{R}$ were conducted. The culture medium was discarded later and the cells were incubated in $4 \%$ paraformaldehyde at room temperature for $10 \mathrm{~min}$. Subsequently, the cells were washed twice with PBS for 3 min each time. Hoechst $33258(0.5 \mathrm{ml})$ was added to each well for $5 \mathrm{~min}$. The cells were washed twice with PBS again. A drop of antifading mounting medium (S2100; Beijing Solarbio Science \& Technology Co., Ltd.) was added to the slide and the slide was then covered with the coverslip carrying the cells. Eventually, the slide was visualized under a fluorescence microscope (magnification, x100; IX51; Olympus Corporation, Tokyo, Japan) with excitation at $350 \mathrm{~nm}$ and emission at $460 \mathrm{~nm}$.

Rat cardiac perfusion tests ex vivo. K-H buffer $(600 \mathrm{ml})$ was added to the reservoir of a Langendorff cardiac perfusion system (Beijing, Zhishuduobao Biological Technology, Beijing, China) and the temperature was adjusted to $37^{\circ} \mathrm{C}$. Next, a gas mixture of $95 \% \mathrm{O}_{2}-5 \% \mathrm{CO}_{2}$ was aerated for $30 \mathrm{~min}$. A total of 28 SD rats (aged 8 weeks) were anesthetized by intraperitoneal injection of $1 \%$ pentobarbital sodium at a dosage of $45 \mathrm{mg} / \mathrm{kg}$. Immediately, the heart was placed in the reservoir containing oxygenic $\mathrm{K}-\mathrm{H}$ buffer at $37^{\circ} \mathrm{C}$. Other tissues around the heart were removed and the remaining blood in the atria and ventricles was extruded by gently squeezing the heart with 
cotton swabs. Retrograde perfusion was performed from the aortic cannula. The heart was fixed with 4-0 sutures. Coronary ischemia and reperfusion were controlled by the switch of perfusion pathway. The flow rate of the perfusate for balancing was $\sim 15 \mathrm{ml} / \mathrm{min}$.

Tests were divided into four groups: Control, sham, H/R and ghrelin (ghrelin $+H / R)(n=7)$. The untreated hearts served as the control. In the sham group, the balancing perfusion was conducted for $20 \mathrm{~min}$. In the H/R group, following balancing for $20 \mathrm{~min}$, improved Thomas II cardioplegic solution was perfused for $3 \mathrm{~min}$ to induce cardiac arrest and then the perfusion was stopped for $30 \mathrm{~min}$. Subsequently, oxygenic K-H buffer was perfused again for $2 \mathrm{~h}$ to induce cardioversion. In the ghrelin group, following balancing for $20 \mathrm{~min}$, ghrelin $(5 \mathrm{mg} / \mathrm{l})$ was perfused for $15 \mathrm{~min}$ and then the normal aerobic perfusion was restored for $15 \mathrm{~min}$. Subsequently, the H/R treatment was performed as demonstrated in the H/R group.

Reverse transcription-quantitative PCR (RT-qPCR). Total RNA was extracted from multiple primary cardiac myocytes and ex vivo myocardial tissues following various treatments using TRIzol reagent according to the manufacturer's protocol. The concentration and purity of the RNA were determined by measuring the absorbance at 260 and $280 \mathrm{~nm}$. Next, the RNA was reverse transcribed to cDNA using a HiFiScript cDNA synthesis kit according to the manufacturer's protocol. The reverse transcription system $(20 \mu \mathrm{l})$ was comprised of dNTP Mix (4 $\mu \mathrm{l})$, primer Mix $(2 \mu \mathrm{l})$, RNA template $(7 \mu \mathrm{l}), 5 \mathrm{X}$ RT Buffer $(4 \mu \mathrm{l})$, dithiothreitol (DTT, $2 \mu \mathrm{l})$ and HiFiScript $(1 \mu \mathrm{l})$. Sequences of the primers, which were synthesized by General Biosystems (Anhui, China), are presented in Table I. The PCR system $(25 \mu \mathrm{l})$ comprised RNase free $\mathrm{dH}_{2} \mathrm{O}(9.5 \mu \mathrm{l})$, cDNA/DNA $(1 \mu \mathrm{l})$, forward primer $(1 \mu \mathrm{l})$, reverse primer $(1 \mu \mathrm{l})$ and 2X UltraSYBR Mixture (12.5 $\mu \mathrm{l})$. Reaction parameters were as follows: Pre-denaturation at $95^{\circ} \mathrm{C}$ for $10 \mathrm{~min}$, denaturation at $95^{\circ} \mathrm{C}$ for $10 \mathrm{sec}$, annealing at $58.5^{\circ} \mathrm{C}$ for $30 \mathrm{sec}$ and elongation for $30 \mathrm{sec}$ at $72^{\circ} \mathrm{C}$, for 40 cycles. Dissociation curve was analyzed as follows: $15 \mathrm{sec}$ at $95^{\circ} \mathrm{C}, 1 \mathrm{~min}$ at $58.5^{\circ} \mathrm{C}, 15 \mathrm{sec}$ at $95^{\circ} \mathrm{C}, 15 \mathrm{sec}$ at $58.5^{\circ} \mathrm{C}$ and $15 \mathrm{sec}$ at $58.5^{\circ} \mathrm{C}$, and measured stepwise from $95^{\circ} \mathrm{C}$, every $0.5^{\circ} \mathrm{C}$. It was finally evaluated on a RT-PCR detection system (CFX Connect ${ }^{\mathrm{TM}}$; Bio-Rad, Laboratories, Inc., Hercules, CA, USA). $\beta$-actin served as an internal control and the expression level relative to $\beta$-actin was calculated using $2^{-\Delta \Delta \mathrm{Cq}}$ method (20).

Western blot analysis. Following various treatments, primary cardiac myocytes were incubated in radioimmunoprecipitation assay (RIPA) lysis buffer in an ice bath for $15 \mathrm{~min}$ and sonicated in an ice bath for another $15 \mathrm{~min}$. Following various treatments, ex vivo myocardial tissues were ground repeatedly in RIPA lysis buffer on ice and sonicated for $15 \mathrm{~min}$. The two types of lysates were centrifuged at $10,000 \times \mathrm{g}$ and $4^{\circ} \mathrm{C}$ for 10 min. The supernatant was collected and mixed with PBS. The mixture was boiled for $5 \mathrm{~min}$ and then centrifuged at $10,000 \mathrm{x} g$ for $5 \mathrm{~min}$ (cells) or $10 \mathrm{~min}$ (tissues). The supernatant was collected to prepare total protein. The concentration was determined using a bicinchoninic acid assay kit (Beyotime Institute of Biotechnology, Haimen, China). Next, protein (20 $\mu \mathrm{g}$ per lane) was loaded to perform SDS-PAGE on $10 \%$ gels. The protein was condensed at $60 \mathrm{~V}$ and separated at
Table I. Sequences of the primers in reverse transcription-polymerase chain reaction.

\begin{tabular}{llc}
\hline Primer & \multicolumn{1}{c}{ Sequence $\left(5^{\prime}-3^{\prime}\right)$} & Length $(\mathrm{bp})$ \\
\hline GH & & 19 \\
Forward & CTGTTTGCCAATGCTGTGC & 19 \\
Reverse & GCTGTCCCTCGGGAATGTA & \\
GHSR & & 21 \\
Forward & CTTCTGCCTCACTGTGCTCTA & 21 \\
Reverse & GCATCTTCACTGTCTGCTTGT & \\
IGF-1 & & 19 \\
Forward & GCACTCTGCTTGCTCACCT & 18 \\
Reverse & CATCCACAATGCCCGTCT & 19 \\
Akt & & 19 \\
Forward & GGCATCTTCTCCTTCCAGC & 18 \\
Reverse & AGAGTTCCTCCACCACCGT & 19 \\
$\beta$-actin & & \\
Forward & AGGGAAATCGTGCGTGAC & 19 \\
Reverse & ATACCCAGGAAGGAAGGCT & \\
\hline
\end{tabular}

GH, growth hormone; GHSR, growth hormone secretagogue receptor; IGF-1, insulin-like growth factor-1; Akt, protein kinase B.

$80 \mathrm{~V}$. Polyvinylidene difluoride membranes were activated by absolute methanol at room temperature for $15 \mathrm{sec}$. Membrane transfer was conducted for $\beta$-actin and GHSR at $300 \mathrm{~mA}$ for $1.5 \mathrm{~h}$, for IGF-1 at $300 \mathrm{~mA}$ for $2 \mathrm{~h}$, for $\mathrm{GH}$ at $200 \mathrm{~mA}$ for $50 \mathrm{~min}$, and for Akt at $200 \mathrm{~mA}$ for $1 \mathrm{~h}$. Next, it was blocked in 5\% BSA buffer at room temperature overnight. The membrane was subsequently incubated in primary antibody buffer at $4^{\circ} \mathrm{C}$ for $3 \mathrm{~h}$. It was rinsed three times for $10 \mathrm{~min}$ each time and incubated in secondary antibody buffer at room temperature for $2 \mathrm{~h}$. It was rinsed three times for $10 \mathrm{~min}$ each time. Following chemiluminescent substrate being added, the membrane was exposed on an imaging system (ChemiDoc XRS+, Bio-Rad Laboratories, Inc., Hercules, CA, USA). Blots were semi-quantitatively analyzed with a Quantity one software (v4.62; Bio-Rad Laboratories, Inc.). $\beta$-actin served as the internal control.

Immunohistochemical analysis. Following various treatments, ex vivo myocardial tissues were collected, fixed in $4 \%$ paraformaldehyde at room temperature for $30 \mathrm{~min}$, embedded with paraffin and cut into slices (thickness, $4 \mu \mathrm{m}$ ). Following heating at $65^{\circ} \mathrm{C}$ for $2 \mathrm{~h}$, the slices were incubated in xylene for $10 \mathrm{~min}$ and in fresh xylene for another $10 \mathrm{~min}$. Subsequently, the slices were immersed successively in $100 \%$ ethanol, 100 ethanol, 95 ethanol, $80 \%$ ethanol and water each for $5 \mathrm{~min}$. The slices were later incubated in citrate buffer in a box and heated to automatic air release in a pressure cooker. After $2 \mathrm{~min}$, the slices were removed and naturally cooled. Following the citrate buffer being removed and the slices being eluted with PBS, the slices were incubated in $3 \%$ fresh hydrogen peroxide in a wet box for $10 \mathrm{~min}$ at room temperature. Subsequently, the slices were washed in PBS three times for $5 \mathrm{~min}$ each 
A
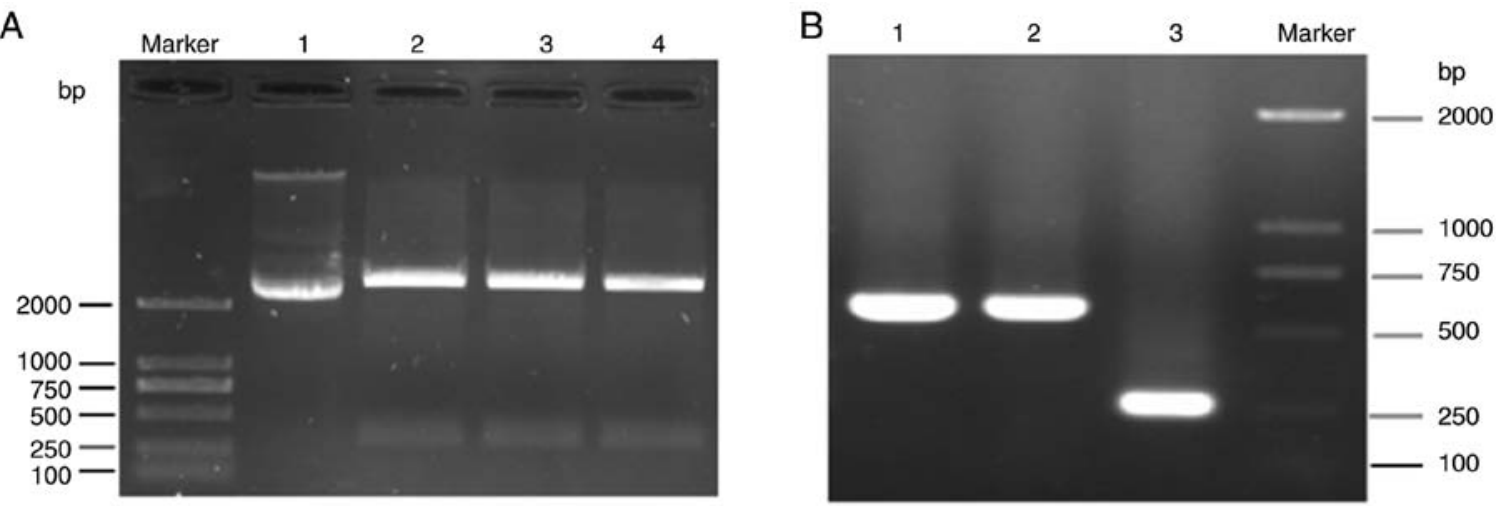

Figure 1. Electrophoretograms of ghrelin and its expression vector. (A) The electrophoretogram of the enzyme digestion product from ghrelin-pUC57 plasmid. The target bands of ghrelin (363 bp) were observed in the lanes of the ghrelin-pUC57 plasmid following incubation with BamHI and EcoRI. 1, ghrelin-pUC57; 2-4, ghrelin-pUC57/EcoRI/BamHI. (B) The electrophoretogram of colony PCR products. The isolated ghrelin from the ghrelin-pUC57 plasmid was ligated to pLVX-Puro vector and two single colonies containing the ghrelin- pLVX-Puro vector were verified by PCR. 1-2, ghrelin-pLVX-Puro; 3, pLVX-Puro; PCR, polymerase chain reaction.

time and $5 \%$ BSA was added dropwise onto the slices at $37^{\circ} \mathrm{C}$ for $30 \mathrm{~min}$. The excess blocking buffer around the tissue was absorbed with absorbent papers. Diluted primary antibodies (all 1:500) were dropwise added onto each slice. Following incubation at $4{ }^{\circ} \mathrm{C}$ overnight in a wet box, the slices were removed for $45 \mathrm{~min}$ at room temperature and then washed in PBS three times for $5 \mathrm{~min}$ each time. Diluted secondary antibody (1:200) was added dropwise onto the slices, which were subsequently incubated at room temperature for $30 \mathrm{~min}$. The slices were rinsed and developed in DAB for 5-10 min followed by rinsing with PBS for $1 \mathrm{~min}$. The slices were then counterstained with hematoxylin at room temperature for 3 min, differentiated in $1 \%$ hydrochloric alcohol, blued, rinsed, dehydrated, transparentized, mounted and examined under a fluorescence microscope (magnification, x200; CKX31; Olympus Corporation).

Statistical analysis. Each experiment was repeated three times. Data are expressed as the mean \pm standard deviation $(\mathrm{SD} ; \mathrm{n}=7)$. Following confirmation of normal distribution by the Kolmogorov-Smirnov test, statistical differences among different groups were analyzed by analysis of variance followed by least significant difference post hoc test using SPSS 19.0 software (IBM Corp., Armonk, NY, USA). P<0.05 was considered to indicate a statistically significant difference.

\section{Results}

Construction of ghrelin expression vector. The electrophoretogram of the enzyme digestion product from ghrelin-pUC57 plasmid is shown in Fig. 1A. There was no band between 250 and $500 \mathrm{bp}$ in the lane of the ghrelin-pUC57 plasmid without enzyme digestion. However, the target bands of ghrelin (363 bp) were observed in the lanes of the ghrelin-pUC57 plasmid following incubation with BamHI and EcoRI.

The isolated ghrelin from the ghrelin-pUC57 plasmid was ligated to a pLVX-Puro vector, and two single colonies containing the ghrelin-pLVX-Puro vector were verified by PCR. In the electrophoretogram of colony PCR verification, the target genes were identified, which demonstrated that the two colonies were positive colonies (Fig. 1B). This confirmed the successful construction of the ghrelin-pLVX-Puro vector.

Isolation and identification of primary neonatal rat cardiac myocytes. The immunofluorescent staining of primary neonatal rat cardiac myocytes was shown in Fig. 2. $\alpha$-sarcomeric actinin was a specific protein of cardiac myocytes. Red and blue fluorescence represented the $\alpha$-sarcomeric actinin and the cell nuclei, respectively. It was demonstrated that all the isolated cells had red $\alpha$-sarcomeric actinin. It was indicated that the primary neonatal rat cardiac myocytes were successfully isolated and cultured.

Cell viability. Fig. 3 demonstrates the viability of primary neonatal rat cardiac myocytes in various groups (control, $\mathrm{H} / \mathrm{R}$, empty and ghrelin) at 24, 48 and $72 \mathrm{~h}$ after treatment (if any), which was examined by CCK- 8 assay. Compared with the control group, the viabilities in other three groups were significantly reduced $(\mathrm{P}<0.05)$, suggesting the inhibition of cell growth by $\mathrm{H} / \mathrm{R}$ treatment. There was no significant difference in the cell viability between the H/R and empty groups. The empty pLVX-Puro vector did not promote cell proliferation. However, the cell viability in the ghrelin group was significantly higher than that in the empty group $(\mathrm{P}<0.05)$, indicating that ghrelin was capable of improving the viability of primary neonatal rat cardiac myocytes.

Cell apoptosis. Fig. 4 demonstrates the apoptosis of primary neonatal rat cardiac myocytes in various groups (control, H/R, empty and ghrelin), which was evaluated by Hoechst staining. Compared with the control group, the apoptosis rates in the other three groups were significantly increased $(\mathrm{P}<0.05)$, suggesting the promotion of cell apoptosis by H/R treatment. The H/R and empty groups exhibited similar apoptosis rates, demonstrating that the empty pLVX-Puro vector had no effect on cell apoptosis. However, the apoptosis rate in the ghrelin group was significantly lower than that in the empty group $(\mathrm{P}<0.05)$, indicating that ghrelin was able to suppress the apoptosis of primary neonatal rat cardiac myocytes and repair the hypoxic cardiac myocytes. 


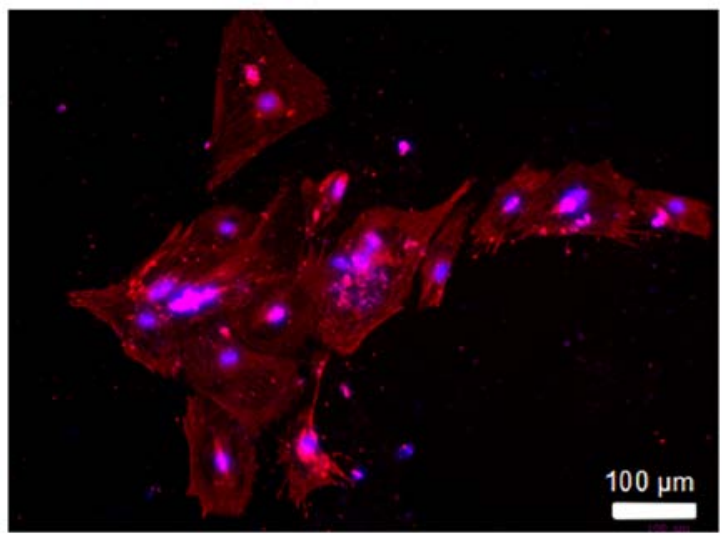

Figure 2. Immunofluorescent staining of primary neonatal rat cardiac myocytes. Red and blue fluorescence represented the $\alpha$-sarcomeric actinin and the cell nuclei, respectively.

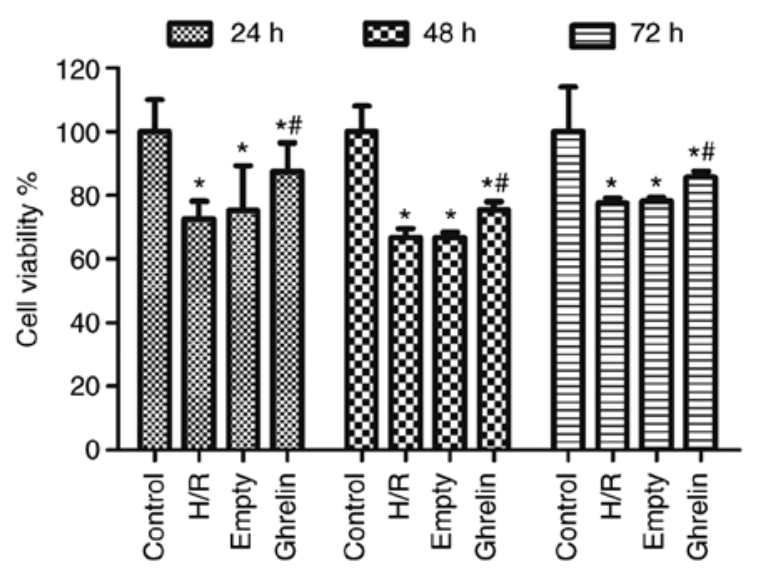

Figure 3. Viability of primary neonatal rat cardiac myocytes in various groups [control, $\mathrm{H} / \mathrm{R}$, empty (empty pLVX-Puro plasmid $+\mathrm{H} / \mathrm{R}$ ) and ghrelin (ghrelin-pLVX-Puro plasmid +H/R)] at 24, 48 and $72 \mathrm{~h}$ after treatment (if any), which was examined by Cell Counting Kit- 8 assay. " $\mathrm{P}<0.05$ vs. the control group; ${ }^{\#} \mathrm{P}<0.05$ vs. the empty group. $\mathrm{H} / \mathrm{R}$, hypoxia/reoxygenation.

Levels of GH, GHSR, IGF-1, Akt and p-Akt in primary cardiac myocytes following various treatments. The mRNA levels of GH, GHSR, IGF-1 and Akt in primary cardiac myocytes in various groups (control, H/R, empty and ghrelin), which were determined by RT-PCR, are presented in Fig. 5A. The protein expression levels of GH, GHSR, IGF-1, Akt and p-Akt in primary cardiac myocytes in various groups (control, $\mathrm{H} / \mathrm{R}$, empty and ghrelin), which were evaluated by western blot analysis, are presented in Fig. 5B. Compared with the control group, the mRNA and protein levels of GH, GHSR and IGF-1 in the other three groups were significantly decreased $(\mathrm{P}<0.05)$, suggesting the downregulation of GH, GHSR and IGF-1 in primary cardiac myocytes by H/R treatment. Similar mRNA and protein levels of GH, GHSR and IGF-1 were discovered between the $\mathrm{H} / \mathrm{R}$ and empty groups, demonstrating that the empty pLVX-Puro vector did not affect the expression of GH, GHSR and IGF-1 in primary cardiac myocytes. Notably, the mRNA and protein levels of GH, GHSR and IGF-1 in the ghrelin group were significantly higher than those in the empty group $(\mathrm{P}<0.05)$, indicating that ghrelin could upregulate the expression of GH, GHSR and IGF-1 in primary cardiac
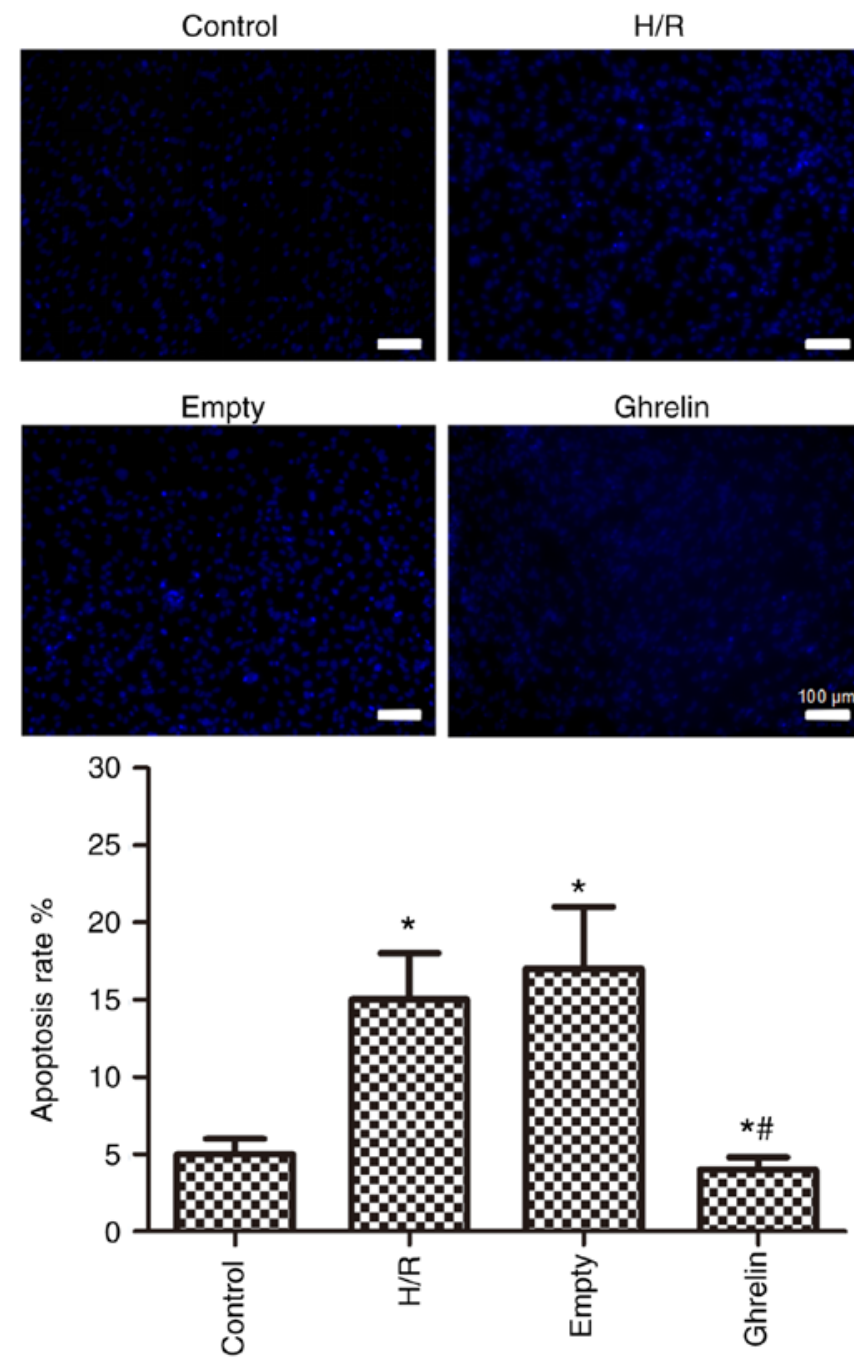

Figure 4. Apoptosis of primary neonatal rat cardiac myocytes in various groups [control, H/R, empty (empty pLVX-Puro plasmid $+\mathrm{H} / \mathrm{R}$ ) and ghrelin (ghrelin-pLVX-Puro plasmid $+\mathrm{H} / \mathrm{R}$ )], which was evaluated by Hoechst staining. ${ }^{*} \mathrm{P}<0.05$ vs. the control group; ${ }^{\#} \mathrm{P}<0.05$ vs. the empty group. $\mathrm{H} / \mathrm{R}$, hypoxia/reoxygenation.

myocytes. It was demonstrated that the mRNA and protein expression levels of Akt were similar among the four groups. It was implied that ghrelin transfection and H/R treatment did not influence the expression of Akt in primary cardiac myocytes. However, compared with the control group, the ratios of p-Akt to Akt protein expression (p-Akt/Akt) in the other three groups were significantly decreased $(\mathrm{P}<0.05)$. The ratio of $\mathrm{p}-\mathrm{Akt} / \mathrm{Akt}$ was similar between the H/R and empty groups. Compared with the empty group, the ghrelin transfection in the ghrelin group significantly increased the ratio of $\mathrm{p}-\mathrm{Akt} / \mathrm{Akt}(\mathrm{P}<0.05)$.

Levels of GH, GHSR, IGF-1, Akt and p-Akt in myocardial tissues following various treatments. The mRNA expression levels of GH, GHSR, IGF-1 and Akt in myocardial tissues in various groups (control, sham, H/R and ghrelin) determined by RT-PCR are shown in Fig. 6A. The protein expression levels of GH, GHSR, IGF-1, Akt and p-Akt in myocardial tissues in various groups (control, sham, $\mathrm{H} / \mathrm{R}$ and ghrelin) evaluated by western blot analysis were demonstrated in Fig. 6B. Compared with the control group, the mRNA and protein expression 

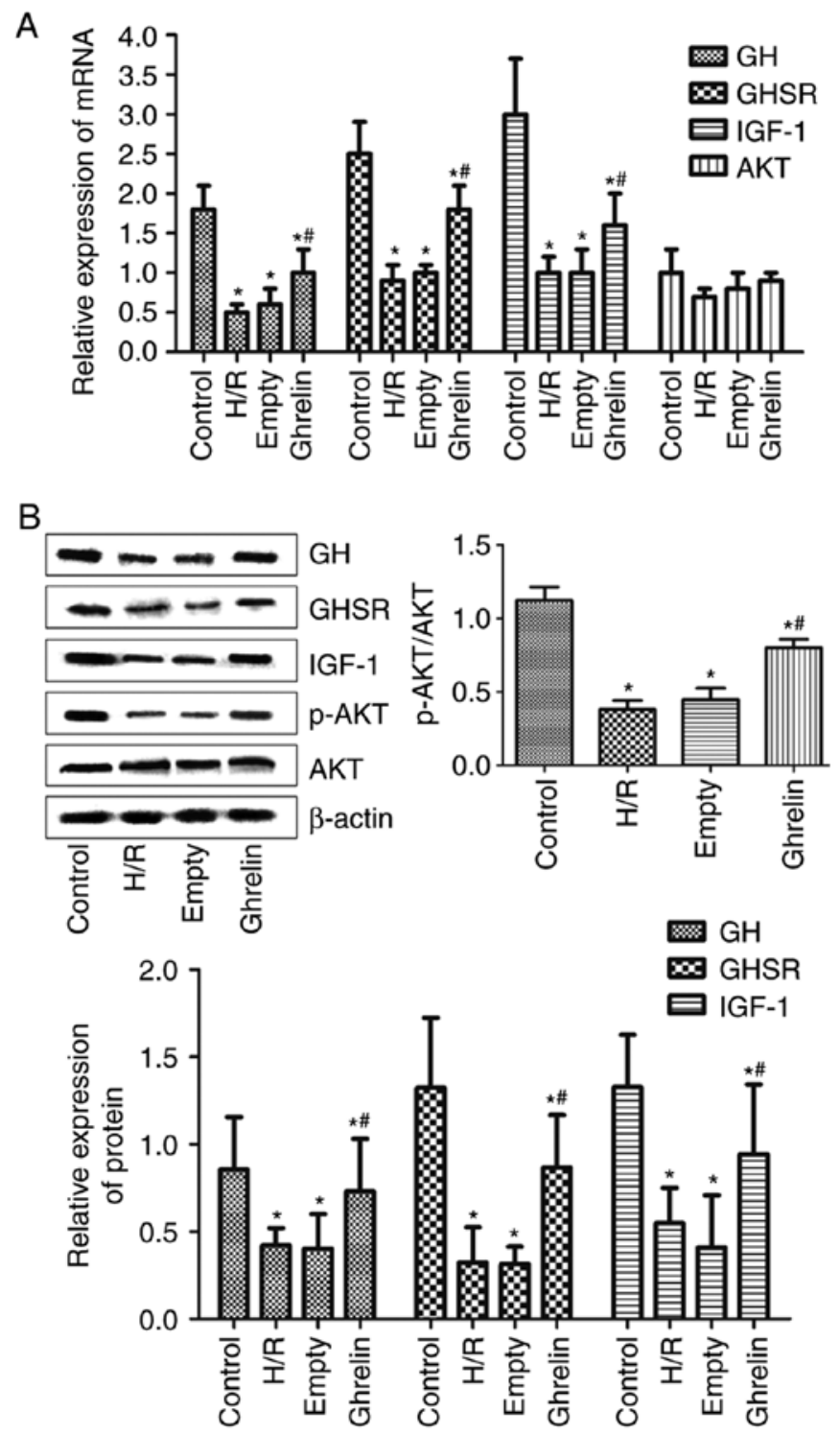

Figure 5. The expression levels of GH, GHSR, IGF-1, Akt and p-Akt in primary cardiac myocytes in various groups. (A) The mRNA expression levels of GH, GHSR, IGF-1 and Akt in primary cardiac myocytes in various groups [control, $\mathrm{H} / \mathrm{R}$, empty (empty pLVX-Puro plasmid $+\mathrm{H} / \mathrm{R}$ ) and ghrelin (ghrelin-pLVX-Puro plasmid $+\mathrm{H} / \mathrm{R}$ )], which was determined by reverse transcription-polymerase chain reaction. (B) The protein expression levels of GH, GHSR, IGF-1, Akt and p-Akt in primary cardiac myocytes in various groups, which was evaluated by western blot analysis. GH, growth hormone GHSR, growth hormone secretagogue receptor; IGF-1, insulin-like growth factor-1; Akt, protein kinase B; p-Akt, phosphorylated Akt. "P<0.05 vs. the control group; ${ }^{~} \mathrm{P}<0.05$ vs. the empty group. $\mathrm{H} / \mathrm{R}$, hypoxia/reoxygenation.

levels of GH, GHSR and IGF-1 in the H/R and ghrelin groups were significantly decreased $(\mathrm{P}<0.05)$, suggesting the downregulation of GH, GHSR and IGF-1 in myocardial tissues by H/R treatment. Similar mRNA and protein expression levels of GH, GHSR and IGF-1 were observed between the control and sham groups. Notably, the mRNA and protein levels of GH, GHSR and IGF-1 in the ghrelin group were significantly higher than those in the $\mathrm{H} / \mathrm{R}$ group $(\mathrm{P}<0.05)$, indicating that ghrelin could upregulate the expression of GH, GHSR and IGF-1 in myocardial tissues. The mRNA and protein expression levels of Akt were revealed to be similar among the four groups. It was implied that ghrelin and $\mathrm{H} / \mathrm{R}$ treatment did not

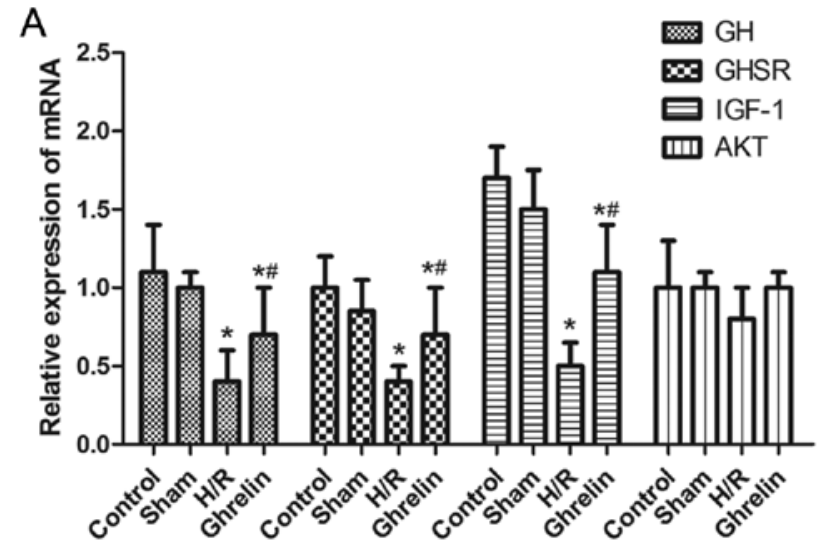

B
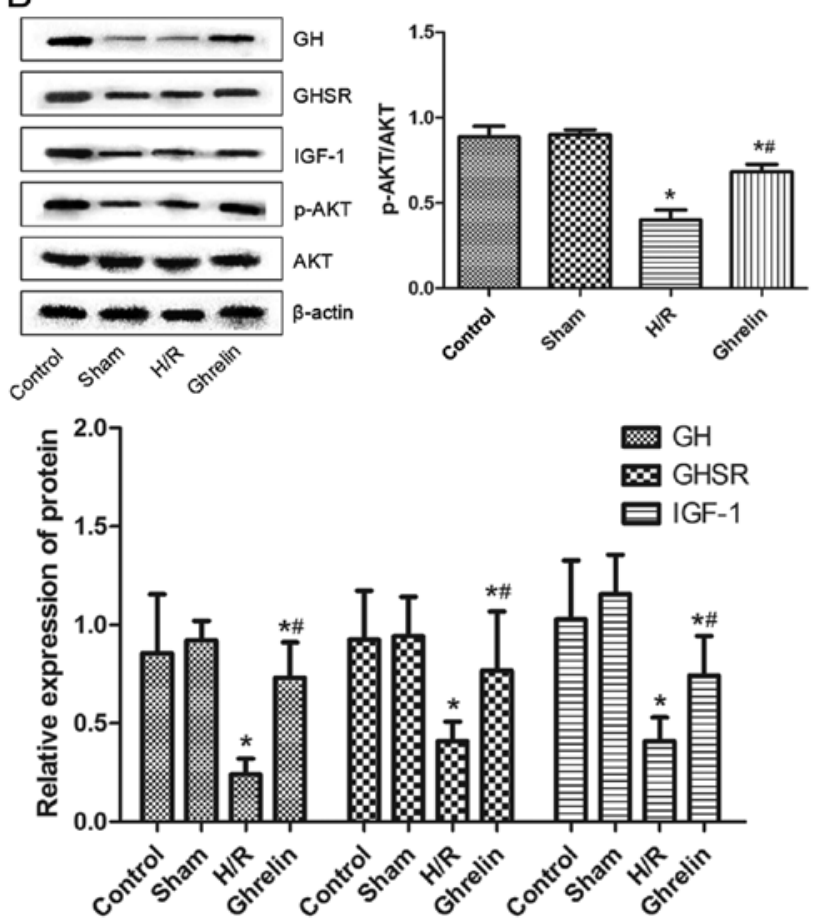

Figure 6. (A) The mRNA expression levels of GH, GHSR, IGF-1 and Akt in myocardial tissues in various groups [control, sham, $\mathrm{H} / \mathrm{R}$ and ghrelin $($ ghrelin $+\mathrm{H} / \mathrm{R})$ ], which was determined by reverse transcription-polymerase chain reaction. (B) The protein expression levels of GH, GHSR, IGF-1, Akt and p-Akt in myocardial tissues in various groups, which was evaluated by western blot analysis. GH, growth hormone; GHSR, growth hormone secretagogue receptor; IGF-1, insulin-like growth factor-1; Akt, protein kinase B; p-Akt, phosphorylated Akt; H/R, hypoxia/reoxygenation. ${ }^{*} \mathrm{P}<0.05$ vs. the control group; ${ }^{\#} \mathrm{P}<0.05$ vs. the $\mathrm{H} / \mathrm{R}$ group.

influence the expression of Akt in myocardial tissues. However, compared with the control group, the ratios of $\mathrm{p}-\mathrm{Akt} / \mathrm{Akt}$ in the $\mathrm{H} / \mathrm{R}$ and ghrelin groups were significantly decreased $(\mathrm{P}<0.05)$. The ratio of p-Akt/Akt was similar between the control and sham groups. Compared to the H/R group, the ghrelin group exhibited a notably larger ratio of $\mathrm{p}-\mathrm{Akt} / \mathrm{Akt}(\mathrm{P}<0.05)$.

Immunohistochemical analysis of GH, GHSR, IGF-1 and Akt in myocardial tissues following various treatments. Fig. 7 depicts the immunohistochemical staining images of GH, GHSR, IGF-1 and Akt in myocardial tissues in various groups (control, sham, H/R and ghrelin). The corresponding protein and the nuclei are stained brown and bluish violet, respectively. The expression levels of GH, GHSR, IGF-1 and 

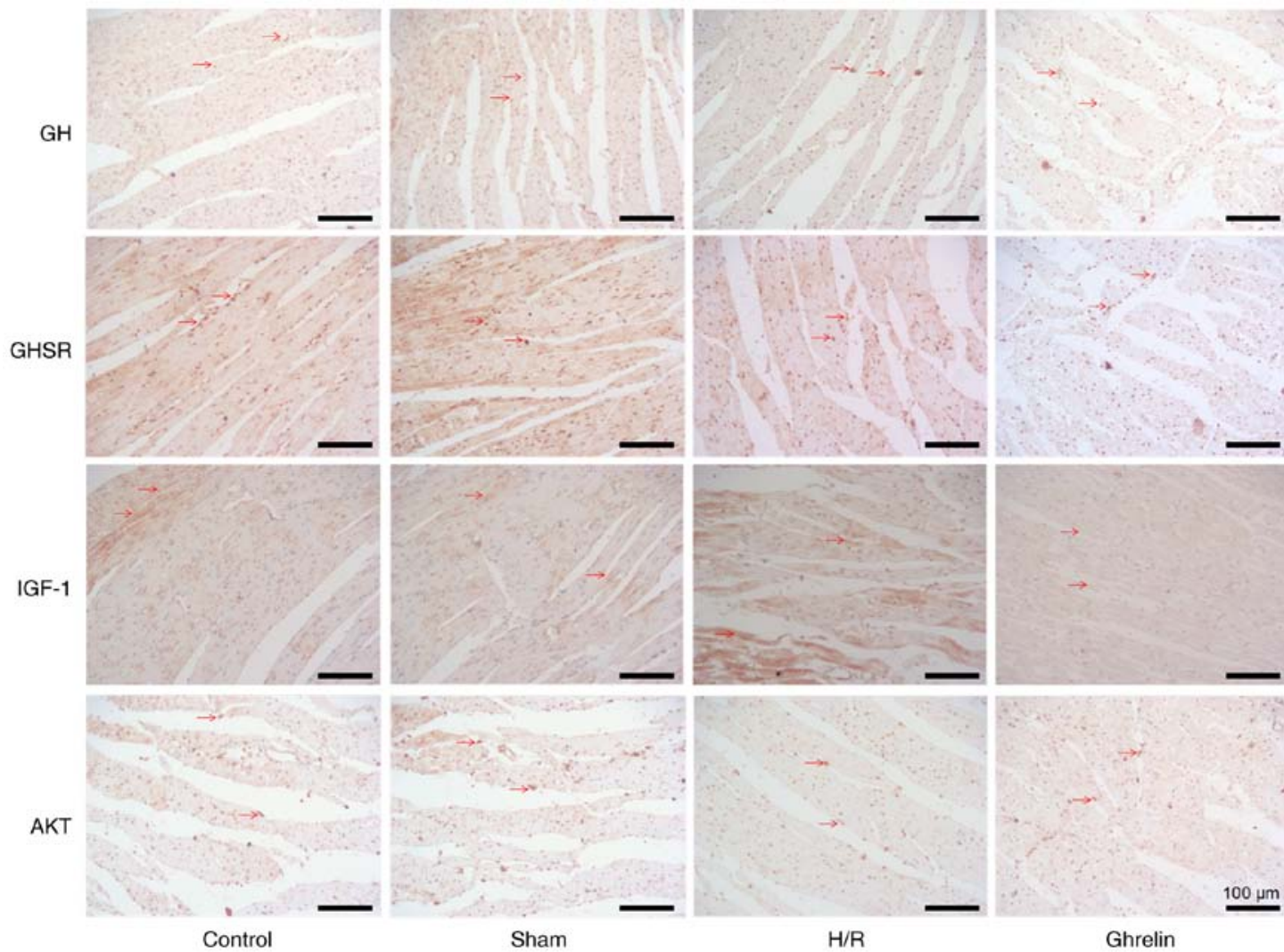

Figure 7. The immunohistochemical staining images of GH, GHSR, IGF-1 and Akt in myocardial tissues in various groups [control, sham, H/R and ghrelin $($ ghrelin $+\mathrm{H} / \mathrm{R})]$. The corresponding protein and the nuclei are shown by brown (arrows) and bluish violet, respectively. GH, growth hormone; GHSR, growth hormone secretagogue receptor; IGF-1, insulin-like growth factor-1; Akt, protein kinase B; H/R, hypoxia/reoxygenation. Magnification, x200.

Akt in the $\mathrm{H} / \mathrm{R}$ and ghrelin groups were intuitively lower than those in the control group. This demonstrated that the myocardial tissues following $\mathrm{H} / \mathrm{R}$ treatment were damaged. However, the expression level of brown protein in the ghrelin group was notably higher than that in the $\mathrm{H} / \mathrm{R}$ group, particularly for GH and GHSR. Furthermore, there were varying degrees of rupture, shrinkage and irregular appearance of the myocardial tissues in the H/R group, and this phenomenon was particularly evident in the IGF-1 protein group. Although there remained certain injuries of the myocardial tissues in the ghrelin group, this was markedly improved compared with the H/R group. Ghrelin enhanced the integrity of cardiac myocytes, and reduced shrinkage and apoptosis.

\section{Discussion}

The reduction of coronary blood flow due to various reasons results in insufficient supply of myocardial oxygen and the reduced elimination of metabolic products; therefore, this clinical condition is known as myocardial hypoxia (21). The majority of cardiac diseases can cause myocardial ischemia and hypoxia, but no radical cure is currently available in clinic. Therefore, to the best of our knowledge, the present study was the first to reveal the improving effect of ghrelin on hypoxic myocardium and the involved molecular mechanisms through constructing primary neonatal rat cardiac myocytes transfected with ghrelin lentiviral expression vector, and evaluating the subsequent cell viability and apoptosis, as well as the expression of associated genes at the cell and tissue levels.
Primary neonatal rat cardiac myocytes were isolated and the immunofluorescent staining of $\alpha$-sarcomeric actinin proved that the isolated cells were the target cells. Improved cellular activity could be obtained through the cell characterization using the isolated primary cells, and this was consistent with the characterization of subsequent $e x$ vivo myocardial tissues. This could more accurately reflect the repair effect of ghrelin on the myocardium at the cell and tissue levels.

CCK-8 and Hoechst assays demonstrated that ghrelin could inhibit the apoptosis of hypoxic cardiac myocytes, and that it had a protective and repair effect on hypoxic cardiac myocytes, which was in agreement with the reported heart protection function of ghrelin $(22,23)$.

Apoptosis is regulated by intracellular apoptosis regulating proteins, which are divided into two categories: Apoptotic protein and anti-apoptotic protein (24-26). The relative balance between apoptotic protein and anti-apoptotic protein following a series of stimuli or injuries determines whether the cell is alive or apoptotic (27). RT-PCR and western blot analysis were conducted to evaluate the expression of five genes, including GH, GHSR, IGF-1, Akt and p-Akt in primary cardiac myocytes following H/R treatment. The present study demonstrated that ghrelin transfection upregulated the expression of GH, GHSR and IGF-1 at the mRNA and protein levels. Furthermore, ghrelin transfection could elevate the ratio of p-Akt/Akt. It was suggested that ghrelin promoted the phosphorylation of Akt, inhibited the activity of Akt (28), and upregulated the expression of GH, GHSR and IGF-1, consequently enhancing the viability and suppressing the apoptosis 
of cardiac myocytes. Additionally, the PI3K/Akt signaling pathway may be inhibited following the phosphorylation of Akt, such that the cardiac myocytes may be repaired $(17,18)$. Ghrelin inhibited the expression of apoptotic proteins and promoted the expression of anti-apoptotic proteins in neonatal rat cardiac myocytes, thereby inhibiting the apoptosis of cardiac myocytes following heart failure and resisting ventricular remodeling; therefore, this may be a mechanism of the anti-apoptotic effect of ghrelin $(28,29)$.

Furthermore, a rat cardiac perfusion model was established ex vivo and the expression of GH, GHSR, IGF-1, Akt and p-Akt in the myocardial tissues following $\mathrm{H} / \mathrm{R}$ treatment was investigated by RT-PCR, western blot analysis and immunohistochemical analysis. Immunohistochemical results demonstrated that ghrelin enhanced the integrity of cardiac myocytes and reduced shrinkage and apoptosis. These results suggested that ghrelin may protect and repair the myocardium through upregulating the expression of GH, GHSR and IGF-1, and ghrelin promoted the phosphorylation of Akt and inhibited the activity of $\mathrm{Akt}$ in myocardial tissues, consequently alleviating the injury of myocardial tissues. This was the same as the results at the cell level. Immunohistochemical analysis of myocardial tissues was performed, but cardiac function was not analyzed. A negative control was not included in the immunohistochemical analysis. These were limitations to the present study.

Ghrelin can improve the cardiac output, left ventricular ejection fraction and change rate of left ventricular maximum pressure, and inhibit left ventricular hypertrophy in rats with chronic heart failure (30). Ghrelin is a natural endogenous ligand for GHSR and is also considered to be a powerful stimulant for the release of $\mathrm{GH}$. Certain studies have demonstrated that the main role of ghrelin in cardiac myocytes is to promote the expression of non-functional GHSR (31). Another report also indicated that, in addition to GHSR, ghrelin may have other unknown receptors in the cardiac repair system (32). According to the results of RT-PCR and western blot analysis, ghrelin promoted the expression of GHSR and GH, and repaired hypoxic cardiac myocytes. Therefore, the possible mechanism was that ghrelin upregulated the expression of GHSR through binding with GHSR, and subsequently GHSR stimulated the overexpression of GH. GH is one of the hormones synthesized and secreted in the adenohypophysis, which has a positive function in the treatment of cardiovascular disease (33). It has been demonstrated that it can stimulate the central nervous system and local organs to produce IGF-1 through autocrine and paracrine mechanisms, which can directly or indirectly influence cardiac tissues, enhance cardiac contractility, reduce cardiac load, improve cardiac function and postpone cardiomyocyte apoptosis $(34,35)$.

Cao et al (14) reported that the cardioprotective effects elicited by ghrelin may contribute toward the inhibition of inflammatory response through the Akt activated pathway. The basic difference between this previous paper and the present study was in the different animal models. This previous paper used a CPB model, while the present study used a model of myocardial injury caused by H/R (14). This was the first time to investigate the therapeutic effect of ghrelin on the model of myocardial injury induced by H/R. Furthermore, in the present study, the cells used in the in vitro cell experiments were isolated from the neonatal rats in the same batch of rats used in the animal experiments ex vivo. Homologous cells and animal materials were selected for the cell and animal experiments to conduct similar H/R treatments, which made the results of the present study more accurate and reliable.

In conclusion, to the best of our knowledge, the present study was the first to reveal that ghrelin protected the primary cardiac myocytes and the myocardium ex vivo with $\mathrm{H} / \mathrm{R}$ treatment through upregulating the expression of GH, GHSR and IGF-1, promoting the phosphorylation of Akt, and inhibiting the activity of Akt. These results may provide novel insight into the understanding of the mechanisms of ghrelin in cardiovascular protection and repair, and provide promising guidance for the clinical application of ghrelin. One limitation of the present study was that inflammation was not investigated. Additionally, a ghrelin blocker group will be added in future studies.

\section{Acknowledgements}

Not applicable.

\section{Funding}

The present study was supported by the Natural Science Foundation of Jiangxi Province of China (grant no. 20171BA B205042) and Jinlei Growth Science Research Foundation for Pediatric Endocrinologist with Young and Middle-Age (grant no. PEGRF201607011).

\section{Availability of data and materials}

The datasets used and/or analyzed during the current study are available from the corresponding author on reasonable request.

\section{Authors' contributions}

YL, ZC and GG designed study and wrote the manuscript. YangL, YanlingL and GL collected and analyzed the data. All authors performed the study.

\section{Ethics approval and consent to participate}

The study protocol was approved by the Ethics Committee of Children's Hospital of Suzhou University (Suzhou, China).

\section{Patient consent for publication}

Not applicable.

\section{Competing interests}

The authors declare that they have no competing interests.

\section{References}

1. Heather LC, Cole MA, Tan JJ, Ambrose LJ,Pope S,Abd-Jamil AH, Carter EE, Dodd MS, Yeoh KK, Schofield CJ, et al: Metabolic adaptation to chronic hypoxia in cardiac mitochondria. Basic Res Cardiol 107: 268, 2012.

2. Suematsu M, Katsuki A, Sumida Y, Gabazza EC, Murashima S, Matsumoto K, Kitagawa N, Akatsuka H, Hori Y, Nakatani K, et al: Decreased circulating levels of active ghrelin are associated with increased oxidative stress in obese subjects. Eur J Endocrinol 153: 403-407, 2005. 
3. Shimizu Y, Nagaya N, Teranishi Y, Imazu M, Yamamoto H, Shokawa T, Kangawa K, Kohno N and Yoshizumi M: Ghrelin improves endothelial dysfunction through growth hormone-independent mechanisms in rats. Biochem Biophys Res Commun 310 830-835, 2003.

4. Lim JA, Baek HJ, Jang MS, Choi EK, Lee YM, Lee SJ, Lim SC, Kim JY, Kim TH, Kim HS, et al: Loss of $\beta 2$-spectrin prevents cardiomyocyte differentiation and heart development. Cardiovasc Res 101: 39-47, 2014.

5. Li CJ, Madhu V, Balian G, Dighe AS and Cui Q: Cross-talk between VEGF and BMP-6 pathways accelerates osteogenic differentiation of human adipose-derived stem cells. J Cell Physiol 230: 2671-2682, 2015.

6. Matsuura K, Honda A, Nagai T, Fukushima N, Iwanaga K, Tokunaga M, Shimizu T, Okano T, Kasanuki H, Hagiwara N and Komuro I: Transplantation of cardiac progenitor cells ameliorates cardiac dysfunction after myocardial infarction in mice. J Clin Invest 119: 2204-2217, 2009.

7. Reich H, Tseliou E, de Couto G, Angert D, Valle J, Kubota Y, Luthringer D, Mirocha J, Sun B, Smith RR, et al: Repeated transplantation of allogeneic cardiosphere derived cells boosts therapeutic benefits without immune sensitization in a rat mode of myocardial infarction. J Heart Lung Transplant 35: 1348-1357, 2016.

8. Mishra PK, Chavali V, Metreveli N and Tyagi SC: Ablation of MMP9 induces survival and differentiation of cardiac stem cells into cardiomyocytes in the heart of diabetics:a role of extracellular matrix. Can J Physiol Pharmacol 90: 353-360, 2012.

9. Nam YJ, Song K and Olson EN: Heart repair by cardiac reprogramming. Nat Med 19: 413-415, 2013.

10. Mouquet F, Pfister O, Jain M, Oikonomopoulos A, Ngoy S, Summer R, Fine A and Liao R: Restoration of cardiac progenitor cells after myocardial infarction by self-proliferation and selective homing of bone marrow-derived stem cells. Circ Res 97: 1090-1092, 2005

11. Shirai M, Joe N, Tsuchimochi H, Sonobe T and Schwenke DO Ghrelin supresses sympathetic hyper-excititation in acute heart failure in male rats-assessing centrally and peripherally mediated pathways. Endocrinology 156: 3309-3316, 2015.

12. Yang B, He K, Zheng F, Wan L, Yu X, Wang X, Zhao D, Bai Y, Chu W, Sun Y, et al: Over-expression of hypoxia-inducible factor- 1 alpha in vitro protects the cardiac fibroblasts from hypoxia-induced apoptosis. J Cardiovasc Med 15: 579-586, 2014

13. Ahluwalia A and Tarnawski AS: Critical role of hypoxia sensor - HIF-1 $\alpha$ in VEGF gene activation. Implications for angiogenesis and tissue injury healing. Curr Med Chem 19: 90-97, 2012.

14. Cao Y, Tang J, Yang T, Ma H, Yi D, Gu C and Yu S: Cardioprotective effect of ghrelin in cardiopulmonary bypass involves a reduction in inflammatory response. PLoS One 8: e55021, 2013

15. Zhong W and Xie W: New strategy for the treatment of hepatic fibrosis. J Clin Hepatol 27: 233-235, 2011 (In Chinese).

16. Yuan TL and Cantley LC: PI3K pathway alterations in cancer: Variations on a theme. Oncogene 27: 5497-5510, 2008.

17. Zheng H, Fu G, Dai T and Huang H: Migration of endothelial progenitor cells mediated by stromal cell-derived factor-1alpha/CXCR4 via PI3K/Akt/eNOS signal transduction pathway. J Cardiovasc Pharmacol 50: 274-280, 2007.

18. Chu K, Jung KH, Lee ST, Park HK, Sinn DI, Kim JM, Kim DH Kim JH, Kim SJ, Song EC, et al: Circulating endothelial progenitor cells as a new marker of endothelial dysfunction or repair in acute stroke. Stroke 39: 1441-1447, 2008.

19. Yu S, Wang H, Yu T and Liu X: Role of Nrf2-ARE signaling pathway in protective effect of hypoxia or pinacidil postconditioning against hypoxia-reoxygenation injury in adult rat cardiomyocytes. Chin J Pathophysiol 29: 1696-1703, 2013.

20. Livak KJ and Schmittgen TD: Analysis of relative gene expression data using real-time quantitative PCR and the $2^{-\Delta \Delta C T}$ method. Methods 25: 402-408, 2001.
21. Kamegai J, Tamura H, Shimizu T, Ishii S, Tatsuguchi A, Sugihara H, Oikawa S and Kineman RD: The role of pituitary ghrelin in growth hormone $(\mathrm{GH})$ secretion: GH-releasing hormone-dependent regulation of pituitary ghrelin gene expression and peptide content. Endocrinology 145: 3731-3738, 2004.

22. Cokkinos DV and Pantos C: Myocardial protection in man-from research concept to clinical practice. Heart Fail Rev 12: 345-362, 2007.

23. Li Q, Li Z, Xu XY, Guo YL and Du F: Neuroprotective properties of picroside II in a rat model of focal cerebral ischemia. Int $\mathrm{J}$ Mol Sci 11: 4580-4590, 2010.

24. Liao YH, Xia N, Zhou SF, Tang TT, Yan XX, Lv BJ, Nie SF, Wang J, Iwakura Y, Xiao H, et al: Interleukin-17A contributes to myocardial ischemia/reperfusion injury by regulating cardiomyocyte apoptosis and neutrophil infiltration. J Am Coll Cardiol 59: 420-429, 2012.

25. Fu Y, Yang W, Wei S, Zhang W, Dai G, Gao H, Zheng P and Dang H: Inhibitory effect of matrine on isoproterenol-induced cardiac hypertrophy via regulation of $\mathrm{p}$-Akt/Akt protein in rat. Chin Hosp Pharm J 34: 505-509, 2014 (In Chinese).

26. Park M, Youn B, Zheng XL, Wu D, Xu A and Sweeney G: Globular adiponectin, acting via AdipoR1/APPL1, protects H9c2 cells from hypoxia/reoxygenation-induced apoptosis. PLoS One 6: e19143, 2011.

27. Xia B, Liu H, Xie J, Wu R and Li Y: Akt enhances nerve growth factor-induced axon growth via activating the Nrf2/ARE pathway. Int J Mol Med 36: 1426-1432, 2015.

28. Hwa JS, Jin YC, Lee YS, Ko YS, Kim YM, Shi LY, Kim HJ, Lee JH, Ngoc TM, Bae KH, et al: 2-Methoxycinnamaldehyde from Cinnamomum cassia reduces rat myocardial ischemia and reperfusion injury in vivo due to $\mathrm{HO}-1$ induction. J Ethnopharmacol 139: 605-615, 2012.

29. Silambarasan T, Manivannan J, Priya MK, Suganya N, Chatterjee S and Raja B: Sinapic acid protects heart against ischemia/reperfusion injury and $\mathrm{H} 9 \mathrm{c} 2$ cardiomyoblast cells against oxidative stress. Biochem Biophys Res Commun 456: 853-859, 2015.

30. Wu W, Zhou X, Liu P, Fei W, Li L and Yun H: Isoflurane reduces hypoxia/reoxygenation-induced apoptosis and mitochondrial permeability transition in rat primary cultured cardiocytes. BMC Anesthesiol 14: 17, 2014.

31. Catak Z, Aydin S, Sahin I, Kuloglu T, Aksoy A and Dagli AF: Regulatory neuropeptides (ghrelin, obestatin and nesfatin-1) levels in serum and reproductive tissues of female and male rats with fructose-induced metabolic syndrome. Neuropeptides 48: 167-177, 2014.

32. Soliman AT, Madkour A, Galil MA, El Zalabany M, Aziz SM and Ansari BM: Growth parameters and endocrine function in relation to echocardiographic parameters in children with ventricular septal defect without heart failure. J Trop Pediatr 47: $146-152,2001$

33. Hudson B, Hidalgo C, Saripalli C and Granzier H: Hyperphosphorylation of mouse cardiac titin contributes to transverse aortic constriction-induced diastolic dysfunction. Circ Res 109: 858-866, 2011.

34. Xu JP, Wang HX, Wang W, Zhang LK and Tang CS: Ghrelin improves disturbed myocardial energy metabolism in rats with heart failure induced by isoproterenol. J Pept Sci 16: 392-402, 2010.

35. Tsukamoto Y, Mano T, Sakata Y, Ohtani T, Takeda Y, Tamaki S, Omori Y, Ikeya Y, Saito Y, Ishii R, et al: A novel heart failure mice model of hypertensive heart disease by angiotensin II infusion, nephrectomy, and salt loading. Am J Physiol Heart Circ Physiol 305: H1658-H1667, 2013.

This work is licensed under a Creative Commons Attribution-NonCommercial-NoDerivatives 4.0 International (CC BY-NC-ND 4.0) License. 